RAD Conference Proceedings, vol. 3, pp. 98-102, 2018

ISSN 2466-4626 (online) | DOI: 10.21175/RadProc.2018.21

www.rad-proceedings.org

\title{
ACTIVITY CONCENTRATION OF URANIUM, THORIUM AND POTASSIUM IN THE URINE OF ROE DEER (C. CAPREOLUS) IN VOJVODINA (NORTHERN PROVINCE OF SERBIA)
}

\author{
Željko Mihaljev*, Milica Živkov-Baloš, Sandra Jakšić, Brankica Kartalović, Nenad Popov
}

Scientific Veterinary Institute "Novi Sad”, Novi Sad, Serbia

\begin{abstract}
The naturally occurring radionuclides are the major source of radiation to which humans are exposed to. A total of 21 samples of roe deer (Capreolus capreolus) from different locations in Vojvodina were tested. The samples were prepared for measuring by microwave digestion. The content of potassium in the samples was determined using atomic absorption spectrometry (AAS) The total content of uranium and thorium were determined using inductively coupled plasma mass spectrometry (ICP-MS). The concentration of the activity of the tested radionuclides was calculated based on their specific activities. It can also be concluded that potassium-40 is the predominant natural radionuclide in urine as compared to other radionuclides and it moved in the range of 128-381 Bq/L. The results of urine analysis showed wide ranges in radionuclide activity concentrations: $18.4-231.9 \mathrm{mBq} / L$ for ${ }^{238} U$, 0.94-11.90 $\mathrm{mBq} / \mathrm{L}$ for ${ }^{235} \mathrm{U}$ and 1.03-89.02 $\mathrm{mBq} / \mathrm{L}$ for ${ }^{232} \mathrm{Th}$
\end{abstract}

Key words: ICP-MS, potassium, thorium, uranium, urine

\section{INTRODUCTION}

Peacetime uses of nuclear energy (nuclear weapons testing, nuclear reactor accidents, industrial and medical use of radioactive compounds) and the application of phosphate mineral fertilizers in agricultural production lead to substantial environmental contamination. Land contaminated with radionuclides represents the first link in the food chain hence the radioactive contamination of crop and livestock production. The largest source of radiation activity in the biosphere is the natural radionuclide potassium-40 [1]. Some other natural radionuclides, which have always been present on Earth, also include radioactive elements such as ${ }^{232} \mathrm{Th},{ }^{235 \mathrm{U}}$ and ${ }^{238} \mathrm{U}$. The exposure to low-level radiation originating from these natural elements has always been affecting all living beings on Earth, This is considered to be background radiation or natural phon. Radioactive radiation can cause cancerous illnesses and other changes in the health of humans and the whole living world in general, thus substantially influencing the changes in the environment.

The "technologically enhanced naturally occurring radioactivity" is attributed to uranium, which is brought to the environment through diverse technological procedures and agro technical measures [2]. Technological development resulted in substantial increase of natural soil radioactivity, predominantly through intensive application of agro technical measures based on the use of artificial phosphate fertilizers that contain substantial amounts of natural uranium. Moreover, mining of ore containing heavy metals (zinc, copper, led) from deep layers of lithosphere and processing thereof, as well as the thermal power stations producing huge amounts of solid waste (ash, cinder) that contain natural radionuclides such as uranium, thorium and their prodigy [3], increase the levels of soil radioactivity. Uncontrolled application of phosphate fertilizers implicates substantial potential for undermining the ecological balance as they represent the most powerful source of ${ }^{238} \mathrm{U}$ and ${ }^{232} \mathrm{Th}$ content in the soil, and hence in plants and other links within the food chain. In a superphosphate, uranium is deposited as highly watersoluble uranyl sulphate - $\mathrm{UO}_{2}\left(\mathrm{SO}_{4}\right)$ and uranosulphate - U(SO4) [4]. In addition, there is a generally accepted public belief that during the 1999 bombing, the area of Vojvodina was polluted with depleted uranium. All of the above factors point to the great current concern and the importance of considering the state of the radioactivity of the environment in Vojvodina [5]. As opposed to other radioisotopes, radioactive decay of ${ }^{238} \mathrm{U}$ and ${ }^{232} \mathrm{Th}$ results in formation of the series of $\mathrm{u}$ nstable nuclei, ${ }^{226} \mathrm{Ra}$ and ${ }^{222} \mathrm{Rn}$ being the most dangerous members of uranium chain. ${ }^{226} \mathrm{Ra}$ is a long half-life $\alpha$-emitter, manifesting affinity for accumulating in bones, while gaseous $222 \mathrm{Rn}$ is responsible for internal irradiation of lung tissues. Emissions of those radionuclides into the environment represent potential significant risk factors for the exposure of local inhabitants to ionizing radiation, as well as for increased levels of natural radiation in particular regions.

The involvement of particular radionuclides into biological cycle is associated with plants' ability to

\footnotetext{
*zeljko@niv.ns.ac.rs
} 
absorb radioactive elements from the soil via their root systems. The amount of radioactive material from the soil absorbed by plants is directly proportional to the pollution emission density in a particular territory [6]. The transfer of radionuclides from the soil into the plants is substantially dependant on the soil type, i.e. its physico-chemical properties that significantly affect the resorption rate of radioactive material. The most important physico-chemical properties include chemical composition (concentration of minerals and content of organic matter), structure (mechanical composition), $\mathrm{pH}$, moisture content and crop density [7].

Roe deer (Capreolus capreolus) are the most numerous representatives of large game in hunting grounds in Serbia. They feed on the so-called. "soft food" (grass, green or dry forest or meadow plants and fruits), the so-called. "tough food" (branches of trees, shrubs, bark trees) as well as on the so-called "hard food" (acorn, chestnuts, beech). In addition to the listed nutrients, roe deer also unwillingly consume the remains of soil, stones and dry needles of conifers. They can live up to 15 years [8]. Roe deer, whose digestive tract is poorly adapted to cellulose digestion, prefer young summer plants, medicinal plants and fruit-bearing plants with narrow leaves which contain much fewer polluting particles from the air. There favourite feed is fresh meadow grass, young wheat grains and ivy, poplar leaves, and blackberries. They also like to eat acorn and nibble on the bark of forest vegetation [9].

A game that lives in certain geographical areas can be a very good bio-indicator of contamination by radioactive residues as it consumes unprocessed vegetable foods and their radius of movement is related to a particular habitat. Therefore, the basic aim of these tests is to determine the level of radioactive contamination of the ecological area by analyzing game urine. Based on these results, locations with increased content of natural radionuclides are determined. This would allow easier monitoring of the degree of contamination of an area in order to improve the environmental protection and preservation of protected and highly protected wildlife. In this respect it should be taken into account that the accumulation of radionuclides is influenced by the endogenous factors (age, sex, health condition of the animal) and exogenous factors (geographical position, hydrographic conditions, soil, climate, plant life) [10]. Considering the way of feeding and free movement in nature, deer as a kind of game, can also usefully serve in environmental control as bioindicators of radioactive contamination.

The removal of harmful substances from the body is done through various organs and is most intensive through the urogenital organs and the digestive tract. The most important quantities of radionuclides, especially natural uranium and its isotopes $235 \mathrm{U}$ and ${ }^{238} \mathrm{U}$, are eliminated by urine and faeces. Uranium compounds, which are taken in through food, quickly pass from the lungs to blood and are eliminated from the body through the kidneys, which makes urine analysis useful for detection of very low contamination by those natural radionuclides for which the kidneys are the "critical organ". The rate of excretion of radionuclides and their compounds from the organism depends on their physico-chemical properties, their concentration, as well as the states and functions of the organs through which the excretion is done. The the absorption excedes the elimination, there is an accumulation of the substances in the organism, and such substances are said to have "cumulative" properties.

\section{MATERIALS AND METHODS}

In order to determine the urine levels of natural radionuclides, the samples were collected from different localities (protected nature reserves) in the territory of Vojvodina. During 2016/17, a total of 21 samples of urine from roe deer were collected. Immediately after the shooting, the tearing of the hull and extraction of the internal organs of the game was carried out. Samples of urine were collected by puncture of the urinary bladder and they were promptly subjected to further laboratory treatment. The samples were prepared by wet digestion using Ethos, Labstation Microwave, Milestone [11]. Potassium content was determined using the method of AA spectrophotometry on Spectr AA-10, Varian, at a wavelength of $766.5 \mathrm{~nm}$ and using cesium as the ionization-suppressor. In nature, potassium-40 is found in a mixture of natural potassium isotopes $(39 \mathrm{~K}$, ${ }^{40} \mathrm{~K}$ and ${ }^{41} \mathrm{~K}$ ) with a mass fraction of $0.0119 \%$.The urine samples levels of potassium-40 activity were calculated from total potassium, using the mass activity value for potassium being $31.561 \mathrm{~Bq} / \mathrm{g} \mathrm{K}$ [12]. Concentrations of thorium and uranium in all the samples were analyzed by a technique of inductively coupled plasma with mass spectrometry, on the Agilent ICP-MS 7700.

Table 1. Instrument parameters for Agilent ICP-MS

\begin{tabular}{|cc|}
\hline RF Power & $1550 \mathrm{~W}$ \\
\hline Smpl Depth & $7.4 \mathrm{~mm}$ \\
\hline Carrier Gas & $0.9 \mathrm{~L} / \mathrm{min}$ \\
\hline Nebulizer Pump & $0.1 \mathrm{rps}$ \\
\hline Integration time (U) & $1 \mathrm{sec} / \mathrm{point}$ \\
\hline S/C Temp & $2^{\circ} \mathrm{C}$ \\
\hline OctP RF & $180 \mathrm{~V}$ \\
\hline Readings/replicate & 3 \\
\hline Detector mode & $\mathrm{pulse}$ \\
\hline Integration time (Th) & $0.1 \mathrm{sec} / \mathrm{point}$ \\
\hline
\end{tabular}

The activity levels of uranium-235 and uranium238 in urine samples were determined according to the total uranium concentration using mass activity values $0.570 \mathrm{~Bq} / \mathrm{mgU}$ for ${ }^{235 \mathrm{U}}$ and $11.10 \mathrm{~Bq} / \mathrm{mgU}$ for ${ }^{238} \mathrm{U}$. The activity of thorium was obtained using a specific activity of $4.11 \mathrm{~Bq} / \mathrm{mgTh}$ for ${ }^{232} \mathrm{Th}$ [12]. The five standard solutions were prepared to $1,2,3,4$ and 5 $\mathrm{ng} / \mathrm{ml}$, for both elements, Th and U. Standard curves with linearity of $\mathrm{R}=0.99$ were obtained. The limit of detection (LOD) in urine samples for uranium, o.6 $\mathrm{ng} / \mathrm{L}$ and for thorium, $3 \mathrm{ng} / \mathrm{L}$ was achieved. Concentrations of $235 \mathrm{U}$ and ${ }^{238} \mathrm{U}$, were obtained by calculation, given the known natural abundance of

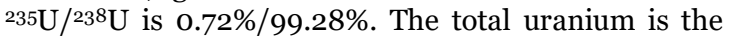
sum of the individual isotope concentrations [13]. Inductively coupled argon plasma mass spectrometry 
(ICP-MS) is a highly useful and practical analytical tool, offering near-simultaneous determination of elemental isotopes with detection limits rivaling or exceeding those of such techniques as graphite furnace AAS and activation analysis. The sample analysis process, from sample preparation to counting and reporting, takes less than a day.

\section{RESULTS AND DISCUSSION}

Table 2 shows the results of the determination of potassium, thorium and uranium concentrations, as well as of the level of activity of ${ }^{40} \mathrm{~K},{ }^{232} \mathrm{Th},{ }^{235} \mathrm{U}$ and
${ }^{238} \mathrm{U}$ natural radionuclides in tested urine samples. Based on the results shown in Table 2, it can be concluded that of all the elements tested, potassium is present in the largest quantities. Its serum concentration ranged from 4.05 (Kulpin) to 12.06 (Futog) g/L corresponding to ${ }^{40} \mathrm{~K}$ activities of $128-381$ $\mathrm{Bq} / \mathrm{L}$. The concentration of $\mathrm{K}$ in urine is very dependent on the amount of $\mathrm{K}$ in food, since all $\mathrm{K}$ from food is resorbed in the small intestine very quickly - it reaches the liver by blood flow and, from there, it is distributed throughout the body. Such K is extremely rapidly excreted in urine [14].

Table 2. The content of natural potassium, thorium and uranium and the activity of the potassium-40, thorium-232, uranium-238 and uranium-235 in samples of roe deer urine

\begin{tabular}{|c|c|c|c|c|c|c|c|}
\hline $\begin{array}{c}\text { Sample } \\
\text { No. }\end{array}$ & $\begin{array}{c}\text { Potassium } \\
{[\mathrm{g} / \mathrm{L}]}\end{array}$ & $\begin{array}{c}{ }^{40} \mathbf{K} \\
{[\mathrm{Bq} / \mathrm{L}]}\end{array}$ & $\begin{array}{c}\text { Thorium } \\
{[\mu \mathrm{g} / \mathrm{L}]}\end{array}$ & $\begin{array}{c}\text { 232Th } \\
{[\mathrm{mBq} / \mathrm{L}]}\end{array}$ & $\begin{array}{c}\text { Uran } \\
{[\mu \mathrm{g} / \mathrm{L}]}\end{array}$ & $\begin{array}{c}\mathbf{2 3 8}^{28} \\
{[\mathrm{mBq} / \mathrm{L}]}\end{array}$ & $\begin{array}{c}\mathbf{2 3 5} \mathbf{U} \\
{[\mathrm{mBq} / \mathrm{L}]}\end{array}$ \\
\hline 1. & 8.00 & 252 & 11.362 & 46.67 & 4.688 & 52.0 & 2.67 \\
\hline 2. & 9.94 & 314 & 1.362 & 5.60 & 2.356 & 26.2 & 1.34 \\
\hline 3. & 7.06 & 223 & 0.812 & $3 \cdot 34$ & 1.956 & 21.7 & 1.11 \\
\hline 4. & 12.06 & 381 & 0.750 & 3.08 & 2.288 & 25.4 & 1.30 \\
\hline 5. & 6.92 & 219 & 0.488 & 2.00 & 2.506 & 27.8 & 1.43 \\
\hline 6. & 9.00 & 284 & 0.512 & 2.10 & 2.662 & 29.6 & $1.5^{2}$ \\
\hline 7. & 9.74 & 307 & 0.388 & 1.59 & 2.356 & 26.2 & 1.34 \\
\hline 8. & 7.95 & 251 & 0.362 & 1.49 & 1.656 & 18.4 & 0.94 \\
\hline 9. & 11.29 & 356 & 0.362 & 1.49 & 2.762 & 30.7 & 1.57 \\
\hline 10. & 10.52 & 332 & 25.775 & 105.9 & 2.831 & 31.4 & 1.61 \\
\hline 11. & 4.24 & 134 & 0.800 & 3.29 & 1.569 & 17.4 & 0.89 \\
\hline 12. & 5.81 & 183 & 14.888 & 61.14 & 20.894 & 231.9 & 11.90 \\
\hline 13. & 5.44 & 172 & 0.900 & 3.70 & 3.031 & 33.6 & 1.73 \\
\hline 14. & 8.51 & 269 & 0.388 & 1.59 & 3.288 & 36.5 & 1.87 \\
\hline 15. & 9.61 & 303 & 21.675 & 89.02 & 4.181 & 46.4 & 2.38 \\
\hline 16. & 6.51 & 206 & 0.738 & 3.03 & 4.088 & $45 \cdot 4$ & 2.33 \\
\hline 17. & 5.94 & 187 & 0.388 & 1.59 & 3.825 & 42.5 & 2.18 \\
\hline 18. & 8.72 & 275 & 8.925 & 36.66 & 3.731 & 41.1 & 2.13 \\
\hline 19. & 6.52 & 206 & 0.412 & 1.69 & 2.856 & 31.7 & 1.63 \\
\hline 20. & 4.05 & 128 & 0.250 & 1.03 & 2.894 & 32.1 & 1.65 \\
\hline 21. & 10.62 & 335 & 0.188 & 0.77 & 3.575 & 39.7 & 2.04 \\
\hline $\begin{array}{c}\text { Variation } \\
\text { Interval }\end{array}$ & $\begin{array}{l}4.05- \\
12.06\end{array}$ & $\begin{array}{c}128- \\
381\end{array}$ & $\begin{array}{l}\text { 0.188- } \\
25.775\end{array}$ & $\begin{array}{c}0.77^{-} \\
105.9\end{array}$ & $\begin{array}{c}1.569- \\
20.894\end{array}$ & $\begin{array}{c}17.40- \\
231.9\end{array}$ & $\begin{array}{l}0.89- \\
11.90\end{array}$ \\
\hline
\end{tabular}

The measured concentrations of thorium in the roe deer urine in most of the tested samples are very low and uniform and are of the same order of magnitude as the values obtained in the kidneys of various wild bird species [15]. In all wild bird samples analyzed, the thorium content was very low and uniform and ranged in the range of $1.40-5.85 \mu \mathrm{g} / \mathrm{kg}$ with an activity of 5.8$24.0 \mathrm{mBq} / \mathrm{kg}$. In some serum samples, the measured values for thorium content were significantly increased and amounted to $8.925 \mu \mathrm{g} / \mathrm{L}=36.66 \mathrm{mBq}^{232} \mathrm{Th} / \mathrm{L}$ (Čenej); $11.362 \mu \mathrm{g} / \mathrm{L}=46.67 \mathrm{mBq}^{232} \mathrm{Th} / \mathrm{L}$ (Čurug); $14.888 \mu \mathrm{g} / \mathrm{L}=61.14 \mathrm{mBq}^{232} \mathrm{Th} / \mathrm{L}$ (Nemanovci); 21.675 $\mu \mathrm{g} / \mathrm{L}=89.02 \mathrm{mBq}{ }^{232} \mathrm{Th} / \mathrm{L}$ (Futog) and $25.775 \mu \mathrm{g} / \mathrm{L}=$ $105.9 \mathrm{mBq}^{232} \mathrm{Th} / \mathrm{L}$ (Čenej). In other urine samples analyzed, the thorium content was very low and uniform and in the range of 0.188 (Čenej)) -1.362 (B.Topola) $\mu \mathrm{g} / \mathrm{L}$ with an activity of $0.77-5.60 \mathrm{mBq} / \mathrm{L}$. Thorium is an ubiquitous element with only radioactive isotopes. Because of its radiation properties and the biokinetics of Thorium-232 following incorporation, it is one of the radioisotopes with the highest radiotoxicity [16].
The largest uranium content $(20.894 \mu \mathrm{g} / \mathrm{L})$ in the urine of the roe deer was measured at the Nemanovci site, with ${ }^{238} \mathrm{U}$ activity $231.9 \mathrm{mBq} / \mathrm{L}$, while the ${ }^{235 \mathrm{U}}$ activity was $11.90 \mathrm{mBq} / \mathrm{L}$. The measured uranium content in all other urine samples was also low and uniform and in the range of 1.656 (Čurug) to 4.688 (Čurug) $\mu \mathrm{g} / \mathrm{L}$, with the activity of ${ }^{238} \mathrm{U}$ in these samples ranging from 18.4 to $52.0 \mathrm{mBq} / \mathrm{L}$ and the activity of 235 $\mathrm{U}$ ranging from 0.94 to $2.67 \mathrm{mBq} / \mathrm{L}$. The measured uranium content in wild bird samples was also low and uniform and ranged in the range of $3.48-11.65 \mu \mathrm{g} / \mathrm{kg}$, with the activity of ${ }^{238} \mathrm{U}$ in these samples ranging from $38.63-129.3 \mathrm{mBq} / \mathrm{kg}$ and the activity of $235 \mathrm{U}$ in the range from 1.98 to $6.64 \mathrm{mBq} / \mathrm{kg}$ [15]. The obtained values for the concentration of the activities of the analyzed radionuclides: ${ }^{40} \mathrm{~K},{ }^{232} \mathrm{Th},{ }^{238} \mathrm{U}$ and ${ }^{235} \mathrm{U}$ can be successfully used to define the natural background of the investigated areas [17], which enables the registration of "technologically increased natural radioactivity", primarily due to the application of modern agro-technical measures based on the use of artificial fertilizers of phosphate origin [4]. 


\section{CONCLUSION}

In all tested urine samples, potassium-40 is the dominant natural radionuclide with an average concentration of activity for all sites, ${ }^{4} \mathrm{~K}_{\mathrm{sr}}=253 \pm 72$ $\mathrm{Bq} / \mathrm{L}$. At locations 1. (Čurug), 10. and 18. (Čenej), 12. (Nemanovci) and 15. (Futog), the measured thorium activity-232, ${ }^{232} \mathrm{Th}_{\mathrm{sr}}=67.9 \pm 25.9 \mathrm{mBq} / \mathrm{L}$ was significantly higher than at other locations, ${ }^{232} \mathrm{Th}_{\mathrm{sr}}=$ $2.34 \pm 1.21 \mathrm{mBq} / \mathrm{L}$. Also, the activity of uranium-238 and uranium-235, as biologically important radionuclides, in urine samples from 1. (Čurug), ${ }^{238} \mathrm{U}_{\mathrm{sr}}$ $=141 \mathrm{mBq} / \mathrm{L}$ and 12 . (Nemanovci), ${ }^{235} \mathrm{U}_{\mathrm{sr}}=31.8 \mathrm{mBq} / \mathrm{L}$ it was higher compared to the other sites, ${ }^{238} \mathrm{U}_{\mathrm{sr}}=31.8$ $\pm 8.3 \mathrm{mBq} / \mathrm{L}$ and $235 \mathrm{U}_{\mathrm{sr}}=1.63 \pm 0.43 \mathrm{mBq} / \mathrm{L}$.For Vojvodina, as an area with great opportunities for the production of health-safe food, it is extremely important to systematically monitor the level of radioactivity of the environment, because if it is contaminated with substances with a technologically elevated level of natural radioactivity, the dose received by the population from radioactive radiation may increase. Method ICP-MS has proved to be a very sensitive method for quantitative determination of Th and $\mathrm{U}$ concentration in urine samples. Therefore, ICPMS offers a useful alternative for monitoring of thorium and uranium in environmental samples. Research in this area and the results obtained contribute to a better understanding of the translocation of radioactive residues from food to certain tissue of game. By determining the level of accumulation of natural radionuclides in the internal organs of wild animals it is possible to estimate the ecological state of geographical areas from which the investigated game originates.

Acknowledgements: The paper is a part of the research done within the project No. TR 31084. The authors would like to thank to the Ministry of Education, Science and Technological Development that financed this project.

\section{REFERENCES}

1. M. Dželalija, "Zračenje u prirodnom okolišu," u Jonizirajuće zračenje u biosferi, Hrvatsk: Kemijskotehnološki fakultet, 2006, pog. 17, sek. 17.3, str. 42 - 45. (M. Dželalija, "Radiactivity in the environment," in Ionizing Radiation in the Biosphere, Croatia: Faculty of Chemistry and Technology, 2006, ch. 17, sec. 17.3., pp. $42-45$.)

Retrieved from: http://djelatnici.unizd.hr/ mdzela/nas tava/KTF.pdf; Retrieved on: Sep. 10, 2017

2. M. Rajković, "Osiromašeni uranijum - Uranijum, radioaktivnost i zakonska regulative," Hem. Ind., vol. 55, br. 4, str.167 - 182, 2001. (M. Rajković "Depleted uranium - Uranium, radioactivity and legal regulations", Chem. Ind. vol. 55, no. 4, pp. $167-182$, 2001.)

Retrieved from: http://www.ache.org.rs/HI/2001/NoO 4/rajkov.pdf;

Retrieved on: Sep. 12, 2017

3. D. Kisić, S. Miletić, V. Radonjić, S. Radanović, J. Filipović, "Prirodna radioaktivnost uglja i letećeg pepela u termoelektrani Nikola Tesla B," Hem. Ind., vol. 67 , br. 5, str. $729-738,2013$.
(D. Kisić, S. Miletić, V. Radonjić, S. Radanović, J. Filipović, "Natural radioactivity of coal and flying ash in a thermal power plant Nikola Tesla B," Chem. Ind, vol. 67, no. 5 , pp. $729-738,2013$.) DOI: 10.2298/HEMIND121016120K

4. B. Mitrović, G. Vitorović, M. Stojanović, D. Vitorović, "Radiaktivnost fosfatnih mineralnih proizvoda," Vet. Glasnik, vol. 65, br. 1-2, str. 123 - 140, 2011 (B. Mitrović, G. Vitorović, M. Stojanović, D. Vitorović, "Radiation of phosphate mineral products," Bull. Vet., vol. 65 , no. 1-2, pp. $123-140,2011$.)

Retrieved from: https://www.researchgate.net/publicat ion/256766052 radioaktivnost fosfatnih mineralnih proizvoda radioactivity of phosphate mineral pro ducts;

Retrieved on: Sep. 11, 2017

5. I. Bikit i dr, Merenje radioaktivnosti zemljišta na teritoriji AP Vojvodine u 2010. godini, Završni izveštaj o realizaciji predmeta ugovora, Univerzitet u Novom Sadu, Novi Sad, Srbija, 2010. (I. Bikit, et al., Measurement of soil radioactivity in the territory of AP Vojvodina in 2010, Final Report on realization of the contract subject, University of Novi Sad, Novi Sad, Serbia, 2010.)

Retrieved from: https://www.scribd.com/document/35 4777167/Merenje-Radioaktivnosti-Zemljista-NaTeritoriii-AP-Vojvodine-u-2010-0;

Retrieved on: Sep. 17, 2017

6. M. Simić, J. Kovačević, B. Radošević, V. Jović, "Prirodni kontaminanti životne sredine", Tehnologija mesa, vol. 42, br. 1-2, str. $45-57$, 2001. (M. Simić, J. Kovačević, B. Radošević, V. Jović, "Natural contaminants of the environment", Meat technology, vol. 42 , no. $1-2$, pp. $45-57,2001$.)

7. S. K. Sahoo et al., "Thorium, Uranium and Rare Elements Concentration in Weathered Japanese Soil Samples," Prog. Nucl. Sci. Technol., vol. 1, pp. 416 - 419, 2011.

Retrieved from: http://www.aesj.or.jp/publication/pnst 001/data/416.pdf;

Retrieved on: Sep. 17, 2017

8. M. Beuković, Z. Popović, "Biološke karakteristike sisara," u Lovstvo, Novi Sad, Srbija: Poljoprivredni fakultet, 2014, pog. 2, sek. 2.1.14.1., str. 18 - 20 . (M. Beuković, Z. Popović, "Biological characteristics of mammals," in Hunting, Novi Sad, Serbia: Faculty of Agriculture, 2014, ch. 2, sec. 2.1.14.1., pp. 18 - 20.)

Retrieved from: http://polj.uns.ac.rs/sites/default/files Ludzbenici/LOVSTVO.pdf;

Retrieved on: Sep. 10, 2017

9. M. Živkov Baloš et al., "The incidence of heavy metals and other toxic elements in Roe Deer (Capreolus Capreolus) Tissues," Arch. Vet. Med., vol. 8, no. 2, pp. $3-10,2015$.

Retrieved from: https://www.researchgate.net/publicat ion/315105665_Milica_Zivkov_Balos_Zeljko_Mihaljev Sandra Jaksic Nadezda Prica Gospava Lazic Milo s Kapetanov Jasna Prodanov Radulovic 2015 The Incidence Of Heavy Metals And Other Toxic Ele ments In Roe Deer Capreolus;

Retrieved on: Sep. 5, 2015

10. Ž. Mihaljev et al., "Radioactivity of the Soil in Vojvodina (Northern Province of Serbia)," in Proc $1^{\text {st }}$ Int. Sym. of Vet. Med. (ISVM2015), Vrdnik, Serbia, 2015, pp. $173-177$.

Retrieved from: http://niv.ns.ac.rs/Proceeding\%20ISV M2015c.pdf:

Retrieved on: May. 21, 2015

11. Ethos one Operator manual, Milestone, Sorisole, Italy, 2005.

Retrieved from: http://prg.ukzn.ac.za/docs/defaultsource/laboratory-documents/microwave-digester(ethos-1).pdf?sfvrsn=2: 
Ž. Mihaljev et al., Activity concentration of uranium, thorium and potassium..., RAD Conf. Proc., vol. 3, 2018, 98-102

Retrieved on: Sep. 26, 2010

12. M. Eisenbud, "The properties of Certain Radionuclides," in Environmental Radioactivity, New York (NY), USA: Academic Press, 1973, pp. $479-494$.

13. R. S. Pappas et al., "Determination of uranium-235, uranium-238 and thorium-232 in urine by magnetic sector inductively coupled plasma mass Spectrometry," J. Anal. At. Spectrom., vol. 17, pp. 131 - 134, 2002. DOI: $10.1039 / \mathrm{b} 108414 \mathrm{c}$

14. I. Jazbec, "Mineralne materije," u Kliničko laboratorijska dijagnostika, Ljubljana, Slovenia: Veterinarski Fakultet, 1999, pog. 19, sek. 19.7. str. 159 - 16o. (I. Jazbec, "Mineral matters," in "Clinical laboratory diagnostics," Ljubljana, Slovenia: Veterinary Faculty, 1999, ch. 19, sec. 19.7., pp. 159 - 160.)

15. Ž. Mihaljev, B. Kartalović, N. Popov, S. Jakšić, M. Živkov-Baloš, "Thorium-232, Uranium-235 and Uranium-238 content in internal organs of wild birds from the area of Vojvodina," in Book of Abstr. $8^{\text {th }}$ Symposium Chemistry and Environmental Protection with international participation (ENVIROCHEM 2018), Kruševac, Serbia, 2018, pp. 191 - 192.

Retrieved from: http://www.envirochem.rs/doc/Enviro Chem 2018--Book of Abstracts.pdf;

Retrieved on: Jun. 12, 2018

16. P. Schramel, I. Wendler, P. Roth., E. Werner, "Method for determination of thorium and uranium in urine by ICP-MS," Mikrochim. Acta, vol.126, no. 3-4, pp. $263-266$, Sep. 1997.

DOI: org/10.1007/BFo1242331

17. A. H. Mohagheghi, S. T. Shanks, J.A. Zigmond, G. L. Simmons, S. L. A. Ward, "A Survey of Uranium and Thorium Background Levels in Water, Urine, and Hair and Determination of Uranium Enrichments by ICP-MS,” J. Radioanal. Nucl. Chem., vol. 263, no 1, pp, $189-195,2005$.

Retrieved from: http://rmcc.foresite-

jo.com/sites/default/files/U-Th-ICPMS-Study.pdf;

Retrieved on: Jun. 19, 2017 